\title{
ELECTRICAL ANAESTHESIA THE USE OF A COMBINATION OF ALTERNATING AND DIRECT ELECTRICAL CURRENT IN DOGS ${ }^{\circ}$
}

\author{
J W R MCINTYRe F F a R C S AND P James Voloshin B SC
}

THE possibirir of producing surgical anaesthesia by electncal means without the use of drugs has been an interestung speculation for many years and the actons of a vanety of alternating or drect currents have been investgated and reviewed ${ }^{1}$ Results were unsatsfactory until Anqn ev produced effectrve anaes thesia in dogs using a constant direct current with a superimposed square-wave alternatng current, ${ }^{2}$ and this was followed by further accounts of the use of such a combination of current ${ }^{37}$ Apparatus similar to that described by Smith and his colleagues $^{37}$ was constructed in this department and reproductions of the wave form produced are shown in Figures 1 and 2 Observations on its use are reported here

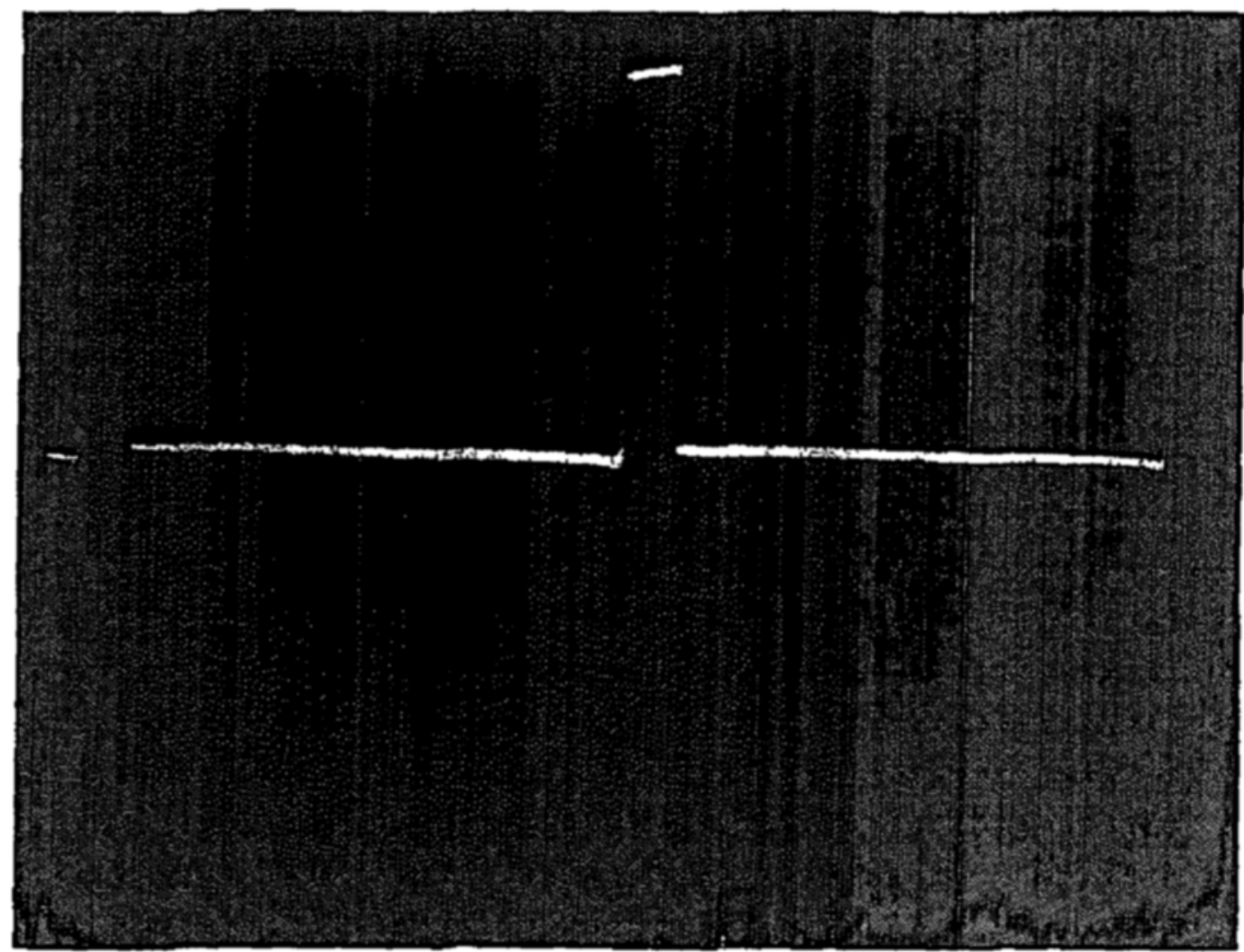

Figure $164 \mathrm{ma} \mathrm{d} \mathrm{c}$ peakng at $168 \mathrm{ma} 200 \mathrm{cps} 1 \mathrm{msec} / \mathrm{cm} \quad 470$ ohm load

A total of eight dogs were used After the administration intravenously of thiopentone $15 \mathrm{mg} / \mathrm{kg}$ the animals were intubated intratracheally and the elec trodes placed in position the cathode on the vertex and the anode on the roof of the mouth Palladium electrodes were used and saturated salme on gauze mantained electrical contact These were maintained in place with a metal elec trode holder ${ }^{8}$ When a clamp applied to the distal inch of the tarl produced umme Alberta

From the Department of Pharmacology and Anaesthesia University of Alberta Edmonton, 


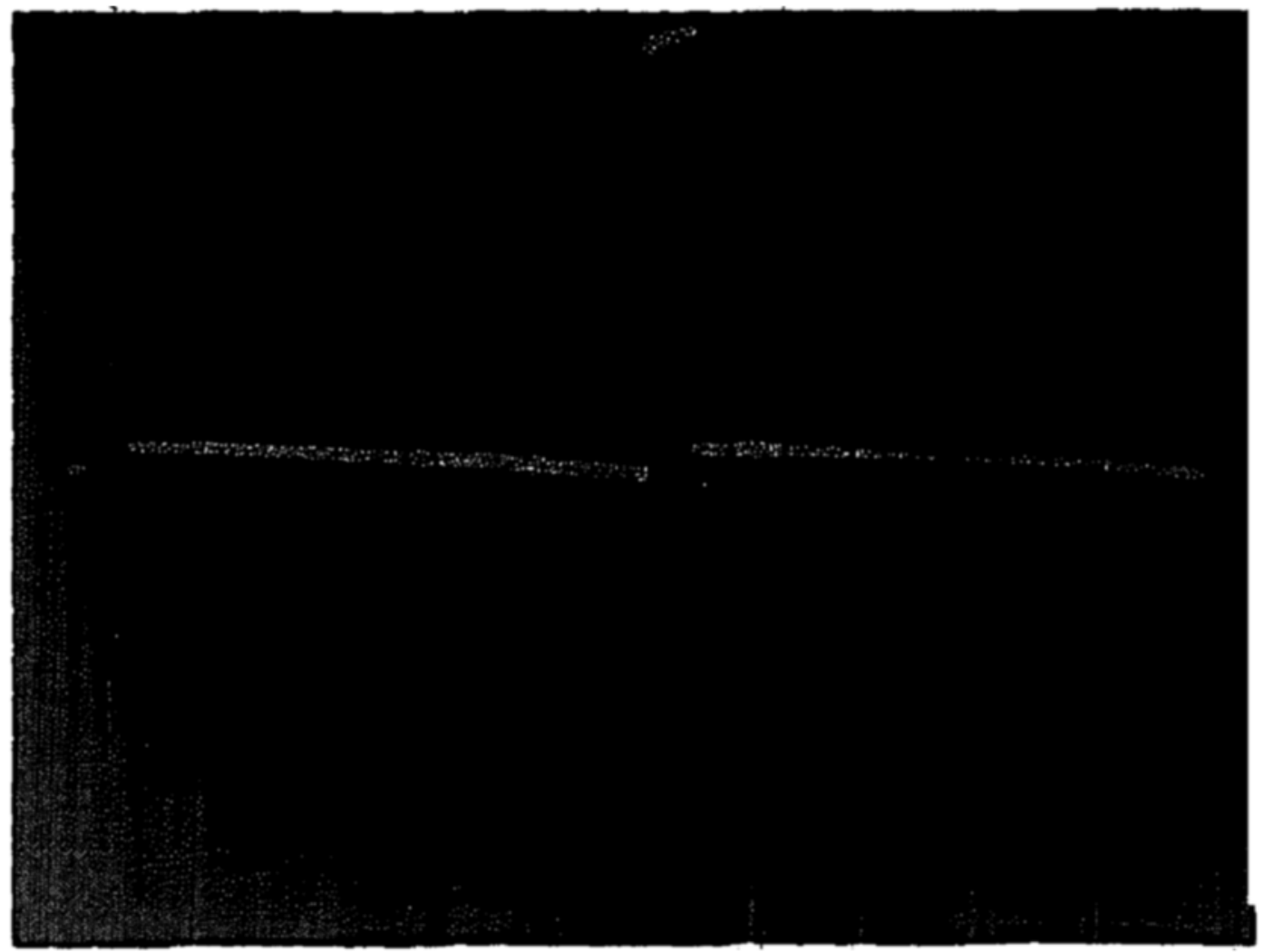

Frgure $285 \mathrm{ma} \mathrm{d} \mathrm{c}$ peaking at $172 \mathrm{mal} 100 \mathrm{cps} 1 \mathrm{msec} / \mathrm{cm} 470$ ohm load

diate and definte movement of limbs and respuratory changes the effect of the thiopentone was considered to have waned sufficiently and observations on the effect of the electric current were begun

In the inthal experments $20 \mathrm{ma} \mathrm{d} \mathrm{c}$ was applied at once Alternating square wave current of $100 \mathrm{cps}$ and $2 \mathrm{msec}$ durration was then introduced more slowly by mechanical means taking approximately 10 minutes for a final current of up to $64 \mathrm{ma}$ peaking at $1680 \mathrm{ma}$ to be reached However associated as they were with severe disturbances of respiration the slower rates appeared to offer only disadvantages and it was found that an increase to $200 \mathrm{cp} \mathrm{s}$ made a more rapid induction with less respiratory disturbance Although a smooth respiratory pattern was established analgesia was almost invariably inadequate Further investigation revealed that a decrease in wave width down to $10 \mathrm{msec}$ and cycles per second to 100 was associated with an increase in effective/analgesia at currents of 12-13 ma peaking to 60-90 ma Analgesia was considered present when there was no limb movement respiratory or blood pressure response to the sustamed application of a clamp to the distal inch of the tal the abdomen and the dorsal surface of the paws The auditory response was tested at this tume with 1 toy pistol and no muscular respinatory or blood pressure response occurred

The technique finally adopted was as follows $20 \mathrm{ma} \mathrm{d} \mathrm{c}$ was applied at once and $200 \mathrm{cps} 20 \mathrm{msec}$ a $\mathrm{c}$ introduced at an even rate durng the next two minut s until a final current of $90 \mathrm{ma}$ peaking to $400 \mathrm{ma}$ was reached Imme drately following this the wave width and frequency were reduced together and the alternating current contmually increased to compensate for the decrease in current flow A wave width of $15 \mathrm{msec}$ at $125 \mathrm{cps}$ was sometimes adequate or there was further reduction to $10 \mathrm{msec}$ at $100 \mathrm{cps}$ Current How varied 
between 12 and $13 \mathrm{ma}$ peaking to $60-90 \mathrm{ma}$ These secondary current changes took another three munutes and the values then remained unchanged throughout the experiment

Anaesthesia was mantained from 1 to $1 \mathrm{x}$ hours The anmals awakened immediately the current was discontunued, apparently none the worse for their experience However, it was considered advisable to give a small dose of thiopentone prior to discontinuing the current to avoid the brief period of excitement associated with the removal of the electrodes

When this technique had been developed the blood pressure and pulse were monitored for one hour by intra-arterial cannulation Unlike experiences with a $700 \mathrm{cps}$ sine wave, significant increases in pressure or pulse rate did not occur except durng induction when there was usually a transient fall of $10-20 \mathrm{~mm}$ Hg This was probably due to changes in respiration which increased in rate, depth, and expiratory effort As the induction contmued the respiration slowed to a rate of $6-10 / \mathrm{mm}$, the tidal volume remained rassed but became smoother and relatively effortless When the wave width reached $10-10 \mathrm{msec}$ it became increasingly stertorous Thus, though limb relaxation would be satisfactory, the abdominal muscles would be tense It was at the tume that respiration tended to become more forceful that the full onset of analgesia seemed to occur, and it was difficult, though often possible, to achieve one without the other Occasionally the hind legs were well relaxed and the fore legs spastic in the early stage of anaesthesia The tongue, neck, and facial muscles contınued to fasciculate throughout the anaesthesia and endotracheal intubation was mandatory Intubation interferes with the dog's heat-regulating mechanısm and temperature increases were of the order of 1-3 degrees Centigrade unless precautions were taken against this Oxygen consumption was measured using the technique of Severinghaus and Cullen ${ }^{9}$ and, when compared with that of the dog under thopentone, was increased by $20-100$ per cent Creatinine clearance tests were performed with three dogs and the glomerular filtration rate was increased from 176 to 215 and 152 to 246 in two and decreased from 278 to $20 \mathrm{ml} / \mathrm{min}$ in the third Adrenaline was administered intravenously to four dogs in varying dosage $113 \mathrm{mg}$, $50 \mathrm{mg}, 526 \mathrm{mg}$, and $100 \mathrm{mg} / \mathrm{kg}$ On no occasion did these imitial injections produce pulse irregularities, and the pulse rate and blood pressure returned to the onginal levels Durnng anaesthesia the pulse remained regular and atropine was omitted after the early experiments The total duration of electric current to which each dog was subjected was 12 hours approximately Post-moriem histological examination of the brains of four animals revealed no abnormality

The technical difficulties with electrode placement and respiratory obstruction in our hands necessitated the use of thiopentone The effect of this drug on the electrical activity of the brain or the relatively low currents used may account for the difference in technique and results of this work from those reported by Smith and his colleagues, although these finding', support the contention that minimizing the ratio of peak to basal current flow reduces muscle response In addition to electrode placement one major problem in assessing results was the inability, using this apparatus, to alter wave form and current flow independently This will be possible in an apparatus now under construction The conclu- 
sion reached was that, although anaesthesia was produced by the particular method described, the raised oxygen consumption, due among other things to increased respiratory work, and the modest degree of muscular relaxation made it unsatisfactory in its present form However, results were much superior to those produced by a $700 \mathrm{cps}$ sine wave used alone and there was the tantalizing umpression that an ideal technique using electric current could be developed

\section{SUMMARY}

Observations on the use of an apparatus producing an alternating square wave superimposed on a direct electnc current are made Thiopentone $15 \mathrm{mg} / \mathrm{kg}$ was administered intravenously to dogs and the animals were intubated When definite muscular, respiratory, and cardıovascular response to painful stımulı had returned, electric current was applied thiough palladium electrodes on the vertex and the roof of the mouth After prelmminary experiments the technique adopted was the ummediate application of $20 \mathrm{ma} \mathrm{d}$-c and introduction of $200 \mathrm{cps} 2 \mathrm{msec}$ wave width a-c during the ensuing two minutes until a final current of 9 ma peaking to $40 \mathrm{ma}$ was reached The wave width and frequency were then reduced simultaneously and the current increased to maintain current flow Wave widths of $15 \mathrm{msec}$ at $100 \mathrm{cps}$ was sometumes adequate or there was further reduction to $10 \mathrm{msec} 100 \mathrm{cps}$ Current flow vaned between 12 and $13 \mathrm{ma}$ peakıng at 60-90 ma These secondary current changes took about three minutes Anaesthesia was maintained for 1-1/4 hours Significant changes in blood pressure did not occur Satisfactory respiratory exchange was maintained during induction but maximal analgesia tended to be associated with deep stertoious respiration Glomerular filtration rate was not significantly diminished Rectal temperature increased 1-3 degrees Centigrade and oxygen consumption increstsed 20-100 per cent above that of the dog under the influence of thiopentone

The conclusion reached was that, although the technique developed was unsuccessful in the production of optrmum conditions for surgery, it was much superior to a $700 \mathrm{cps}$ sine wave current, and it was thought that a satisfactory technique of electncal anaesthesia would ultumately be developed

\section{RéSUMÉ}

Nous farsons des observations au sujet d'un apparell pouvant produre une onde de courant alternatıf superposée à un courant électrique contınu direct Nous avons donné à des chiens du thıopentone par voie endoveıneuse à la dose de $15 \mathrm{mg} / \mathrm{kg}$, et les avons intubés Lorsque nous avons pu obtenır une réponse muscularre, respiratoire et cardio-vasculaire positive aux stımuli douloureux, nous avons appliqué un courant électrique au moyen d'électrodes de palladium appl1quées sur le vertex et sur le plafond de la bouche Après des essars prélıminarres, la technique adoptée a consisté en l'application immédiate d'un courant direct de $20 \mathrm{ma}$ et l'introduction d'une onde de courant alternatif de $200 \mathrm{cps} 2 \mathrm{~ms}$ au cours des deux minutes survantes jusqu' $\mathrm{à} \mathrm{ce} \mathrm{que} \mathrm{nous} \mathrm{ayons} \mathrm{atteint} \mathrm{un} \mathrm{courant}$ final de $9 \mathrm{ma}$ à $40 \mathrm{ma} \mathrm{La}$ largeur de l'onde et sa fréquence étaient, par la surte, 
simultanément réduites et le courant augmenté pour maintenir le débit Des largeurs d'onde de $15 \mathrm{~ms}$ à $100 \mathrm{cps}$ étarent quelquefors suffisantes, ou nous faisions une réduction additionnelle à $10 \mathrm{~ms} 100 \mathrm{cps}$ Le débit du courant a varié entre 12 et $13 \mathrm{ma}$ avec sommet à 60-90 ma Ces changements de courant secondaures ont nécessité environ trois minutes

L'anesthésı s'est maintenue durant 1 heure à $1 \frac{1}{4}$ heure Nous n'avons pas observé de changements importants de la tension arténelle Au cours de l'induction, les échanges respiratoires se sont maintenus, mas l'analgésie maximale a semblé s'accompagner d'une respiratıon profonde et stertoreuse La filtration glomérulaure n'a pas dımınué de façon importante La température rectale s'est élevée de 1 à 3 degrés centigrades et la consommation d'oxygène a augmenté de 20 à 100 pour cent au-dessus de celle du chen soumıs à l'anesthésie au thiopentone

Nous en sommes venus à la conclusion que, bien que la technıque mise à point n’a pas été efficace pour produrre des conditions opératorres optima, elle s'est avérée bien supérieure à celle de $700 \mathrm{c} p \mathrm{~s}$ sans onde de courant, et nous avons l'ımpression qu'une technıque satısfaisante d'anesthésie électrique pourrait ulténeurement être mise au point

\section{REFERENCES}

1 Van Poznax, A Electncal naesthesia Review Anesthesiology 24101 (1963)

2 Anan'ev, N G et al Preliminary Data on Expenmental Electronarcosis Induced with Apparatus of the Scientific Research Institute of Expenmental Surgical Apparatus and Instruments Anesthesiology 21215 (1960)

3 SMrri, Robert H et al Electronarcosis Produced by a Combination of Direct and Alternating Current A Prelıminary Study Anesthesiology 22163 (1961)

4. Volprtro Perry, $\mathrm{P}$ et al Electronarcosis with Alternating Plus Direct Current Anesthesiology 23164 (1962)

5 Boureau, M J L'Electro-relaxation et l'électro-anesthésıe Anesthésıe Analgésıe Réanımation 19747 (1962)

6 Smrth, Robert H \& Cullen, Stuart C Electronarcosis-A Progress Report Am J Med Electron 1308 (1962)

7 Ruju, P \& Branca, P Electronarcosis by a Combination of Direct and Penodic Current, Proc 1st European Congress of Anaesthesiology 2 195-1 (1962)

8 Smith, Robert H \& Cullen, Stuart C. Electronarcosis by a Combination of Direct and Alternating Current Anesthesiology 23682 (1962)

9 Severinghaus, J W \& Cullen, S C Depression of Myocardium and Body Oxygen Consumption with Fluothane Anesthesiology 19: 165 (1958) 